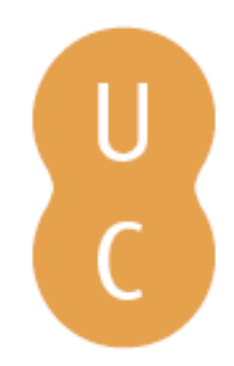

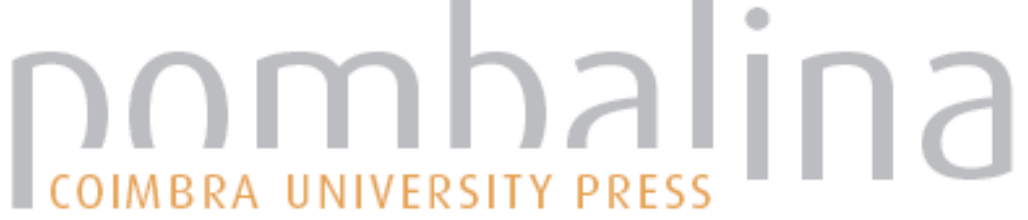

Severe fire activity and associated atmospheric patterns over Iberia and North Africa

Autor(es): $\quad$ Amraoui, Malik; Pereira, Mário G.; DaCamara, Carlos C.; Calado, Teresa

Publicado por: Imprensa da Universidade de Coimbra

URL

persistente: URI:http://hdl.handle.net/10316.2/34281

DOI: DOI:http://dx.doi.org/10.14195/978-989-26-0884-6_102

Accessed : $\quad$ 26-Apr-2023 11:38:32

A navegação consulta e descarregamento dos títulos inseridos nas Bibliotecas Digitais UC Digitalis, UC Pombalina e UC Impactum, pressupõem a aceitação plena e sem reservas dos Termos e Condições de Uso destas Bibliotecas Digitais, disponíveis em https://digitalis.uc.pt/pt-pt/termos.

Conforme exposto nos referidos Termos e Condições de Uso, o descarregamento de títulos de acesso restrito requer uma licença válida de autorização devendo o utilizador aceder ao(s) documento(s) a partir de um endereço de IP da instituição detentora da supramencionada licença.

Ao utilizador é apenas permitido o descarregamento para uso pessoal, pelo que o emprego do(s) título(s) descarregado(s) para outro fim, designadamente comercial, carece de autorização do respetivo autor ou editor da obra.

Na medida em que todas as obras da UC Digitalis se encontram protegidas pelo Código do Direito de Autor e Direitos Conexos e demais legislação aplicável, toda a cópia, parcial ou total, deste documento, nos casos em que é legalmente admitida, deverá conter ou fazer-se acompanhar por este aviso. 


\section{ADVANCES IN}

Forest Fire

\section{RESEARCH}

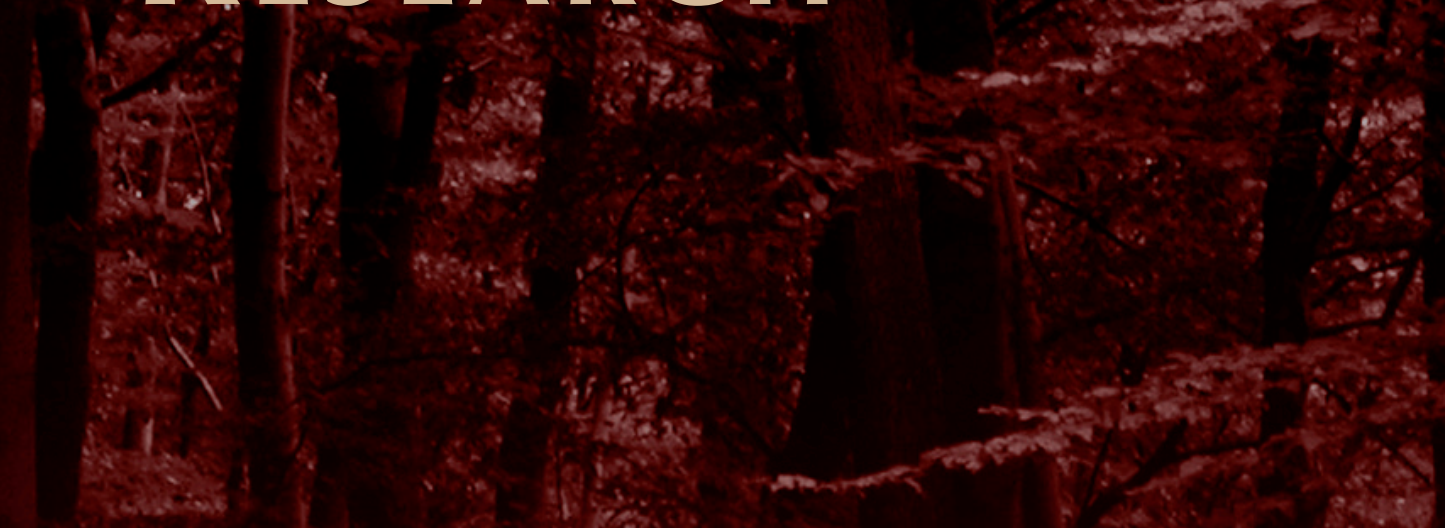

\section{DOMINGOS XAVIER VIEGAS}

\section{EDITOR}




\title{
Severe fire activity and associated atmospheric patterns over Iberia and North Africa
}

\author{
Malik Amraoui $^{\mathrm{a}, \mathrm{b}}$, Mário G. Pereira ${ }^{\mathrm{c}, \mathrm{a}}$, Carlos C. DaCamara ${ }^{\mathrm{a}}$, Teresa J. Calado ${ }^{\mathrm{a}}$ \\ ${ }^{a}$ Instituto Dom Luiz, Universidade de Lisboa, Lisboa, Portugal, malik@utad.pt, cdcamara@fc.ul.pt, \\ mtcalado@fc.ul.pt \\ ${ }^{b}$ Universidade de Trás-os-Montes e alto Douro, UTAD, Quinta de Prados, 5000-801 Vila Real, \\ Portugal, \\ ${ }^{c}$ Centro de Investigação e de Tecnologias Agro-Ambientais e Biológicas CITAB, Universidade de \\ Trás-os-Montes e alto Douro, UTAD, Quinta de Prados, 5000-801 Vila Real, Portugal, \\ gpereira@utad.pt
}

\begin{abstract}
Biomass burning is extremely important at the global, regional and local scales and has impressive impacts at the atmospheric, climatic, environmental and socio-economical levels. The temperate biome of the Mediterranean regions is characterised by rainy and mild winters followed by warm and dry summers that make the region especially prone to the occurrence of a large number of summer fire events. In this context, the 10year (2003 - 2012) MODIS fire data, provided by the MODIS Fire Team (University of Maryland) is used to characterize the spatial and the temporal distribution of fire activity over western region of the Mediterranean basin, paying special attention to large fire episodes. Finally, an assessment of the role of meteorological conditions on large fire events is performed based on the analysis of low and mid atmospheric fields of geopotential, air temperature, relative humidity and wind.
\end{abstract}

Keywords: Extreme fire activity; MODIS; Fire pixels; fire weather; atmospheric circulation patterns; Mediterranean

\section{Introduction}

Biomass burning is an extremely important process from local to global scales with significant impacts at the atmospheric, environmental and socio-economical levels. Encompassing the lands around the Mediterranean Basin is associated to Mediterranean type of forests, woodlands, and shrub. This temperate biome is characterised by rainy and mild winters followed by warm and dry summers that make the region especially prone to the occurrence of a large number of fire events and to the onset of extreme episodes that account for the bulk of burned area in the whole fire season (Pereira et al., 2005, Trigo et al., 2006; Amraoui et al., 2010). The Western part of Mediterranean basin, which includes the Iberian Peninsula, Southern France and Sardinia in Europe and Northern coastal areas of Morocco, Algeria and Tunisia in North Africa, has been the most affected by vegetation fires in the last decades (Schmuck et al., 2013). In the above mentioned countries, fire ignition is strongly conditioned by human behaviour and socioeconomic activities (Costa et al., 2010). Nevertheless, natural factors like the morphology of the landscape, land use, land cover, weather and climate strongly affect wildfire activity (Amraoui et al., 2013). In fact, weather and climate have a profound influence on all stages and aspects of biomass burning from ignition, spread and behaviour up to severity and effects (Benson et al., 2008).

The vast majority of burned area in Mediterranean regions is due to a reduced number of extreme events that occur during a short period of time, and are associated to several atmospheric processes interacting at different temporal and spatial scales (Pereira et al., 2005). These facts motivate focusing attention on the extreme events of fire activity and on the role of weather conditions on fire activity during these cases. 
In terms of accuracy and reliability, satellite information appears as a very appealing tool to monitor fire activity over the entire globe and have led to the development of a consistent long-term record of global fires (Justice and Korontzi, 2001) due to: (i) its homogeneity in space and time and (ii) its several advantages over classical databases of ground-based measurements where the computation of burned area or number of fire occurrences not only depend on the policies of the different countries but are also usually estimated by visual inspection (Pereira et al., 2011; Amraoui et al., 2013).

In this context, the Moderate Resolution Imaging Spectroradiometer (MODIS) on board the polar orbiting Terra and Aqua satellites of National Aeronautics and Space Administration (NASA) Earth Observing System (launched in 1999 and 2002, respectively) was the first instrument with spectral characteristics designed specifically for active fire detection (Kaufman et al., 1998) and, consequently, the MODIS active fire product (Justice et al., 2002) is the most consistent database of burned area and active fires at different spatial and temporal scales (Csiszar el al., 2005; Oom and Pereira, 2013).

The main objective of this work is to use the 10-year (2003 - 2012) database of the MODIS active fire product, composed by daily numbers of fire pixels: $(i)$ to characterize the extreme fire activity episodes (hereafter EFAE) occurred over the Iberian Peninsula and the Northern Africa, throughout the year (extending the study to the months outside the fire season) and (ii) to characterize the associated meteorological conditions of these extreme events based on the analysis of low and mid atmospheric fields such as wind, air temperature, relative humidity, mean sea level pressure and geopotential.

\section{Data and Methods}

\subsection{Active fire data}

The fire dataset covers a 10-year period, from January 2003 to December 2012, of the MCD14ML Collection 5 active fire product (Justice et al., 2002), obtained from MODIS imagery data with a spatial resolution of $1 \mathrm{~km}$ at nadir. Fire detection is performed using a contextual algorithm that exploits the strong emission of mid-infrared radiation from fires and is based on brightness temperatures derived from the 3.9 and $10.5 \mu \mathrm{m}$ channels (Giglio et al., 2003).

During the considered 10-year period, there is a grand total of 126887 fire pixels detected in the study area. The spatial distribution of these fire pixels suggests the existence of two separated sub-regions with highest fire activity namely, the Northern and Western parts of Iberian Peninsula (hereafter NWIP) and the Northern Africa and South-Eastern Iberia (hereafter NAFR) accounting for about 57\% and $40 \%$ of the grand total, respectively. This evidence is even consubstantiated by the impressive anti-correlation $(-99 \%)$ between relative number of fire activity in these two sub-regions (Figure 1).

\subsection{Meteorological data}

The meteorological conditions associated to extreme fire activity were derived using the horizontal fields of ERA-Interim data (Dee et al., 2011) provided by the European Centre for Medium-Range Weather Forecasts (ECMWF). The following meteorological data were extracted over the Western Mediterranean sector $\left(30^{\circ} \mathrm{W}-20^{\circ} \mathrm{E}, 20^{\circ} \mathrm{N}-60^{\circ} \mathrm{N}\right)$, at $12 \mathrm{UTC}$, for the period of 30 years $(1983-2012)$, and then projected onto a $0.75^{\circ} \times 0.75^{\circ}$ latitude/longitude grid:

- mean sea level pressure (hereafter MSLP);

- air temperature at 2 metres height (hereafter T2m);

- wind speed and direction at 10 metres (hereafter W10m);

- air temperature, geopotential height and relative humidity at $850 \mathrm{hPa}$ which corresponds to approximately $1500 \mathrm{~m}$ of altitude (hereafter T850, Z850 and RH850, respectively); geopotential height at $500 \mathrm{hPa}$, in the mid atmosphere, at about $5000 \mathrm{~m}$ of altitude (hereafter Z500). 


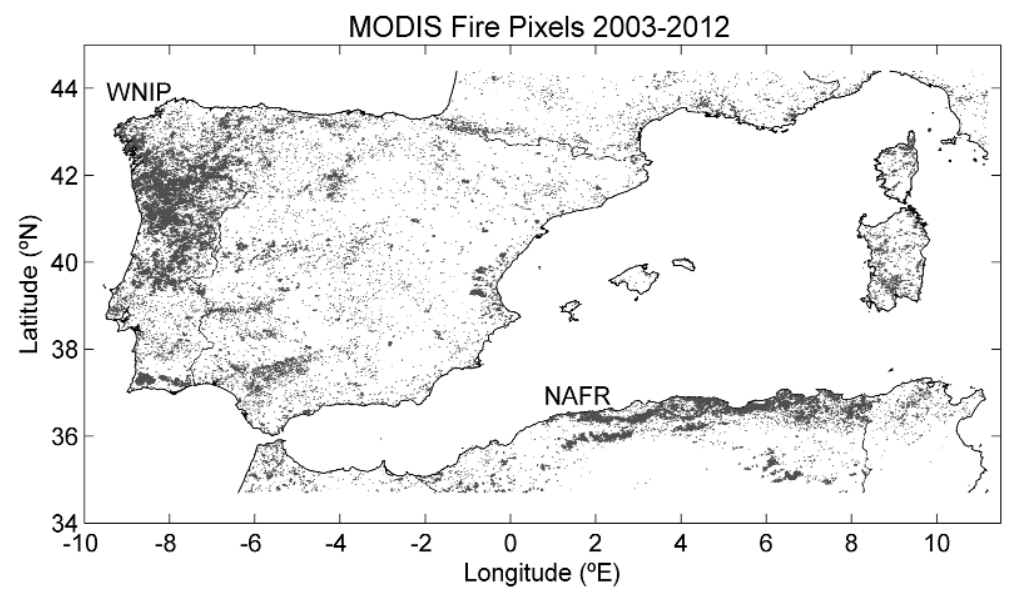

Figure 1. MODIS Fire pixels over Western Mediterranean region from January 2003 to December 2012.

\subsection{Methods}

The EFAE throughout the study period were identified by the use of two criteria: $(i)$ at least 3 consecutive days with number of fire pixels above the $95^{\text {th }}$ percentile; and, (ii) a minimum of 10 fire pixels per day in the same sub-region. These criteria led to the identification of a total number of 35 EFAE with the following spatial distribution: 31 of cases in NWIP; 3 events in NAFR; and 1 particular case that cannot be clearly classified in any of the previous clusters. It is worth noting that 18 of EFAE located in NWIP sub-region have occurred during summer period (May to October) and the remaining 13 episodes during winter period (November to April). On the other hand, all the 3 EFAE occurred in the NAFR sub-region were detected in the summer months (June, July and August).

An assessment of the role played by the meteorological conditions during the EFAE may be performed by analysing the associated horizontal patterns of meteorological fields. For this purpose, reference fields of meteorological variables were computed for each day of the year by averaging the respective 12 UTC meteorological fields for the same day over the entire reference period of 1983 - 2012. Daily anomalies were then computed as departures of each daily field from the reference field (for that day). Finally, composites and anomalies of the meteorological fields were derived by averaging the field's daily values and anomalies for the days of each EFAE.

\section{Results}

An exhaustive analysis of all meteorological variables listed in section 2.2 was performed for each day of the 34 EFAE. The spatial patterns of the obtained composites and anomalies allow stating that the atmospheric conditions were very similar for all days of EFAE in each sub-region and season which lead to the definition of three clusters of EFAE, namely NWIP-Summer, NWIP-Winter and NAFRSummer.

The similarity between the meteorological patterns of each day of the EFAE associated to the same cluster, leads to present results of only one case for each cluster that illustrate the typical atmospheric conditions associated to extreme fire activity of the respective cluster. The chosen extreme episodes are: 11 - 18 October 2011, 21 February - 2 March 2012 and 27 - 30 August 2007 corresponding to the NWIP-Summer, the NWIP-Winter and the NAFR-Summer clusters, respectively. For sake of simplicity, only the anomaly composites of meteorological variables obtained for each EFAE will be presented (Figures 2 to 4 ). 


\subsection{The episode of 11 - 18 October 2011 (NWIP-Summer)}

The anomalous synoptic conditions at the surface (Figure 2b) and at $850 \mathrm{hPa}$ (Figure 2c) are characterized by an amplified Azores anticyclone extending from the Atlantic to Central Europe and by a sub-Saharan thermal low centred at South Algeria. The MSLP and W10m dynamical fields over the region are characterised by isobars with SE-NW orientation and geostrophic winds resulting from the convergence of NE winds over Europe and SE winds from the Northern Africa. This circulation pattern leads to strong North-Eastern and South-Eastern advections of continental dry and warm air, resulting in high surface air temperatures over the Western Iberia and in the extreme air temperature anomalies, exceeding $7^{\circ} \mathrm{C}$ in both 2 metres height temperature and temperature at $850 \mathrm{hPa}$.



Figure 2. MODIS Fire pixels (red dot) over Western Mediterranean region detected during the EFAE of 11 - 18 October 2011 belonging to the NWIP-Summer cluster (upper left panel). The associated anomalies composites of multiple low and mid atmospheric fields are also shown: (b) air temperature $\left({ }^{\circ} \mathrm{C}\right)$ at $2 \mathrm{~m}$ height (T2m) mean sea level pressure (MSLP) and wind $\left(\mathrm{m} \cdot \mathrm{s}^{-1}\right)$ at $10 \mathrm{~m}$ (W10); (c) relative humidity (\%) at $850 \mathrm{hPa}(\mathrm{RH} 850)$ and geopotential height (gpm) at $850 \mathrm{hPa}(\mathrm{Z850})$; (d) air temperature $\left({ }^{\circ} \mathrm{C}\right)$ at $850 \mathrm{hPa}(\mathrm{T850})$ and geopotential height (gpm) at $500 \mathrm{hPa}$ (Z500).

Relative humidity at $850 \mathrm{hPa}$ level reveals the presence of very dry air over the Western and the Northern parts of the Iberian Peninsula reaching the impressive value of $25 \%$ with anomalies lower than $-35 \%$. Composite of the atmospheric flow at $500 \mathrm{hPa}$ (not shown) reveals synoptic baroclinic activity with a pronounced ridge with axes in the Southwest to Northeast direction over the Atlantic Ocean and at Iberia, forcing warmer and drier air mass into the NWIP sub-region. The patterns of composite anomalies at $500 \mathrm{hPa}$ level (Figure 2d), exhibit positive departures of $135 \mathrm{gpm}$ enhancing 
the subsidence of air into the Troposphere and reinforcing the increase of air temperature through adiabatic heating at lower levels.

\subsection{The episode of 21 February - 2 March 2012 (NWIP-winter)}

The synoptic conditions are characterized by an anticyclonic blocking activity over Eastern Atlantic which evolved in altitude into a predominant omega pattern located West of Europe and constituted by the huge high-pressure ridge and two troughs, the first one positioned over Central Atlantic at West of the Canary Isles, and the second one over Central Europe. It is worth stressing that the above mentioned anomalous circulation patterns at the low and mid-Troposphere levels exhibit positive departures of Z850 and Z500 reaching, respectively, to the impressive values of about 100 and $200 \mathrm{gpm}$ (Figures 3c and 3d) North of the Iberian Peninsula.

The temperature anomalies over the sub-region are lower than the previous episode reaching values of about $3^{\circ} \mathrm{C}$ for both the T2m ant T850 temperatures (Figures $3 \mathrm{~b}$ and $3 \mathrm{~d}$ ). As in the preceding episode, relative humidity at $850 \mathrm{hPa}$ level shows the presence of very dry air over the sub-region decreasing to the impressive value of $30 \%$ with anomalies lower than $-40 \%$.

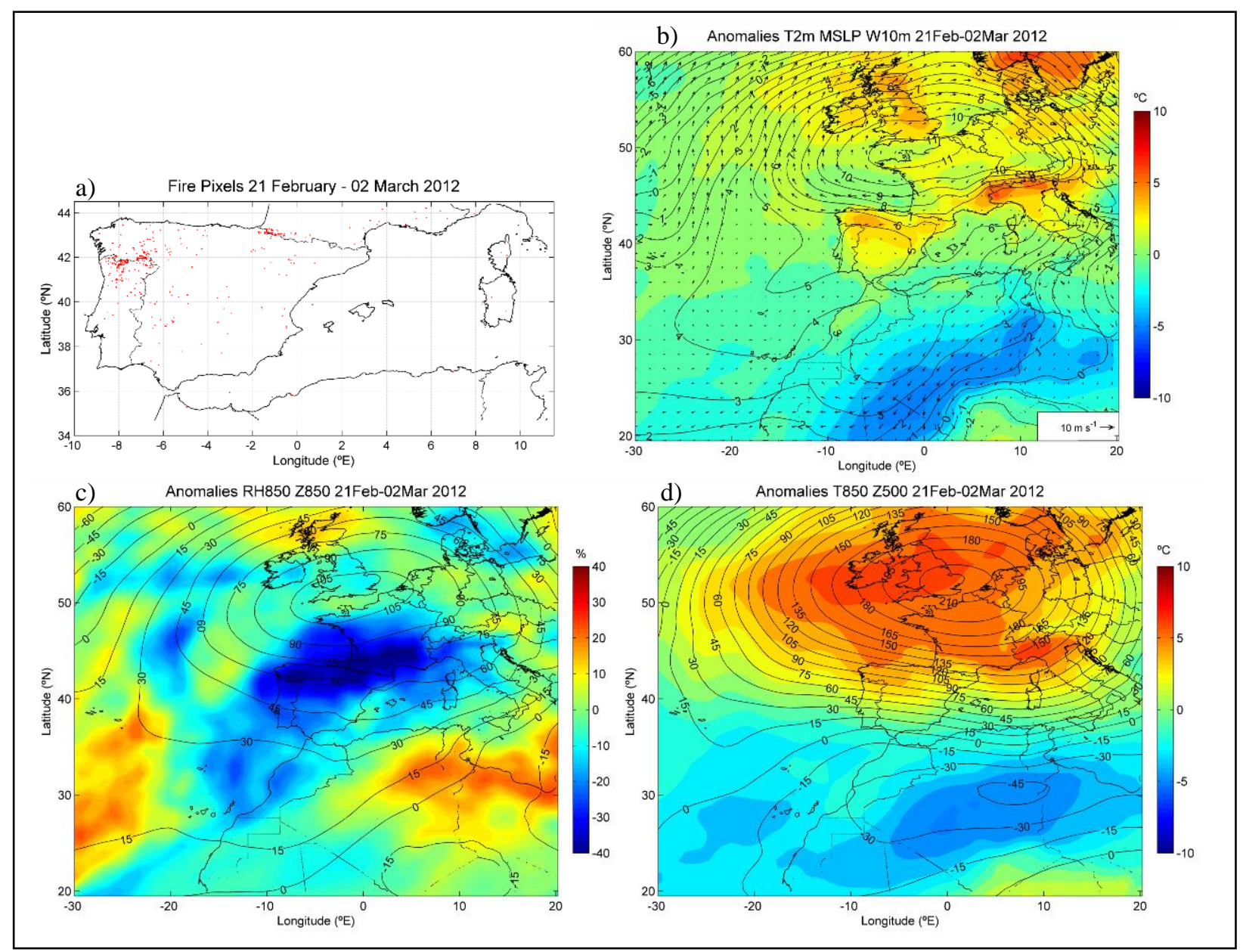

Figure 3. As in Figure 2 but respecting to the EFAE of 21 February - 2 March 2012 belonging to the NWIP-Winter cluster.

\subsection{The episode of 27-30 August 2007 (NAFR-Summer)}

The atmospheric conditions of the episode occurred during the month of August 2007 in North African sub-region is quite different from those obtained for NWIP during winter or summer periods. At the surface, the circulation is dominated by an intense Southerly/South-Easterly advection of very hot and 
very dry Saharan air, brought to the region by the anticyclonic circulation centred over South Italy and the cyclonic flow due to the presence of a Saharan heat low centred over South-Western Algeria and to the Atlas Low located in Central Morocco. The associated high departure values of air temperature (above $7{ }^{\circ} \mathrm{C}$ ) obtained in both T2m and T850 (Figures $4 \mathrm{~b}$ and $4 \mathrm{~d}$ ), and very low departure values of relative humidity at $850 \mathrm{hPa}$ reaching the value of $-25 \%$ (Figure 4c) are well apparent over this subregion.

The atmospheric circulation at the $500 \mathrm{hPa}$ level is dominated by a pronounced ridge whose axis is directed from Southwest to Northeast (not shown), affecting the Northern Algeria and Tunisia and bringing warmer and drier air mass to the region. It may be observed that the location of the referred ridge over Western Mediterranean basin is associated to positive departures of Z500 of about 60 gpm (Figure 4d), which delimit a region over Eastern part of Iberia and Northern Algeria and Tunisia, revealing a region characterized by enhancement of the air subsidence into Troposphere, leading to an increase of air temperature through adiabatic heating at lower levels.

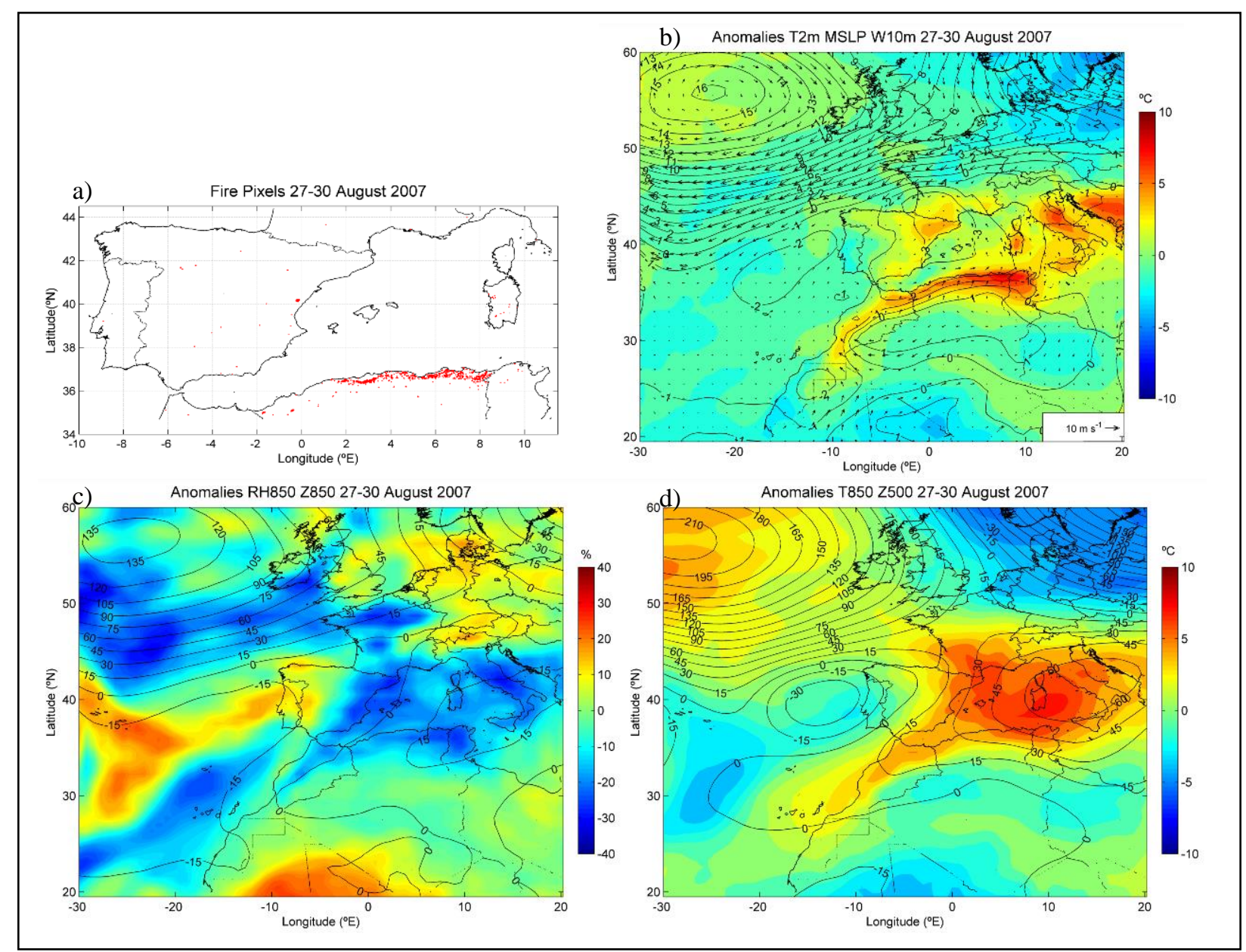

Figure 4. As in Figure 2 but respecting to the EFAE of 27 - 30 August 2007 belonging to the NAFR-Summer cluster.

\section{Conclusions}

The main objective of the present study is to identify and characterize the atmospheric conditions associated with extreme fire activity episodes occurred over Iberia and Northern Africa mainly because: $(i)$ these regions comprises the European and North African countries most affected by fires 
(Pereira et al., 2011, Schmuck et al., 2013); and, (ii) weather and climate proved to be the most important factor to the fire regime in the region (e.g. Rasilla et al., 2010; Amraoui et al, 2013).

The spatial distribution of fire pixels detected by MODIS over Western Mediterranean region during the 10-year (2003 - 2012) period reveals the existence of two sub-regions particularly affected by this natural hazard (Figure 1): the Western and Northern parts of Iberian Peninsula (NWIP); and SouthEastern Iberia and Northern region of Algeria and Tunisia, in North of Africa (NAFR).

The non-seasonal approach used in this study, based on the two criteria mentioned in section 2.3, allows the identification of the major extreme fire activity episodes over the region and the determination of the associated atmospheric patterns, applying the methodology previously validated for Portugal, Italy and Greece during summer (Pereira et al., 2005; Trigo et al., 2013; Amraoui et al., 2013). Thereby, the EFAE were identified in the two sub-regions: 3 episodes observed in the NAFR sub-region and occurred during summer season (June, July and August) and 31 episodes detected in the NWIP and occurred throughout the year even outside the summer fire season, 13 of them during the winter season (November to May) and the remaining 18 episodes during the summer season (June to October). Accordingly, all EFAE were grouped into 3 clusters depending on the sub-region and on the season of occurrence: NWIP-summer, NWIP-winter and NAFR-summer clusters. The similarity between the meteorological patterns of the EFAE associated to the same cluster, leads to present results of only one case for each cluster that illustrate the typical atmospheric conditions associated to extreme fire activity of the respective cluster.

The most important features of the meteorological anomaly fields associated with the presented 3 EFAE belonging to the 3 different clusters are the positive anomalies of T2m and T850 and the impressive negative anomalies of RH850 over most of the corresponding sub-region. It is worth noting that the temperature parameter (T2m) is not the most critical factor to the occurrence of vegetation fires during the winter season. For instance, the T2m of the EFAE belonging to the NWIP-Winter cluster presented in this study (21 February -2 March 2012), reached a small value of $13^{\circ} \mathrm{C}$ (with an anomaly that does not exceed $3^{\circ} \mathrm{C}$ ) over the NWIP sub-region corresponding to a typical value for the mentioned sub-region and season.

The atmospheric circulation patterns of the EFAE occurred in NWIP during summer and winter are essentially characterized by Eastern advection of air at surface and higher levels usually associated to the influence of the Azores high pressure system and the occurrence of heat waves episodes during summer and Atlantic anticyclone blocking events during winter which imply clear sky conditions and enhanced of radiative heating/cooling over the sub-region.

Atmospheric patterns responsible for the occurrence of EFAE in NAFR sub-region during summer season are dominated by very hot and dry South-Easterly winds (Scirocco winds), due to the anticyclonic circulation centred over South Italy, and by the cyclonic flow resulting from the presence of a Saharan heat low centred over South-Western Algeria and the Atlas Low located in Central Morocco. The atmospheric circulation at the $500 \mathrm{hPa}$ level is dominated by a pronounced ridge affecting the Northern Algeria and Tunisia that brings warmer and drier air mass to the sub-region.

Finally, the identification and characterization of the atmospheric conditions associated with extreme fire activity episodes is of paramount importance for $(i)$ the planning and management of fire prevention activities and fire suppression resources, because the time of occurrence and persistence of such conditions may be predicted with current weather forecasting systems for periods of days up to a $1-2$ weeks and (ii) to improve future projections of fire activity based on estimated changes on their frequency, magnitude and duration for different scenarios of climate change (Dury et al., 2010; Pereira et al., 2013). 


\section{References}

Amraoui M, Calado T, Pereira M, DaCamara C (2010) High fire activity and associated atmospheric circulation patterns over the Mediterranean basin. EGU General Assembly 2010 12, EGU201015533

Amraoui M, Liberato MLR, Calado TJ, DaCamara CC, Pinto Coelho L, Trigo RM, Gouveia CM (2013) Fire activity over Mediterranean Europe based on information from Meteosat-8. Forest Ecology and Management 294, 62-75.

Benson RP, Roads JO, Wiese DR (2008) Climatic and weather factors affecting fire occurrence and behaviour. In 'Developments in Environment Science'. (Eds A Bytnerowicz, M Arbaugh, A. Riebau, C. Andersen) 8, pp. 37-59. ISSN: 1474-8177. DOI: 10.1016/S1474-8177(08)00002-8.

Costa L, Thonicke K, Poulter B, Badek FW (2010) Sensitivity of Portuguese forest fires to climatic, human, and landscape variables: subnational differences between fire drivers in extreme fire years and decadal averages. Regional Environmental Change 11(3), 543-551.

Csiszar I, Denis L, Giglio L, Justice CO, Hewson J (2005) Global fire activity from two years of MODIS data. International Journal of Wildland Fire 14, 117-130.

Dee DP, Uppala SM, Simmons AJ, Berrisford P, Poli P, Kobayashi S, Andrae U, Balmaseda MA, Balsamo G, Bauer P, Bechtold P, Beljaars ACM, van de Berg L, Bidlot J, Bormann N, Delsol C, Dragani R, Fuentes M, Geer AJ, Haimberger L, Healy SB, Hersbach H, Hólm EV, Isaksen L, Kållberg P, Köhler M, Matricardi M, McNally AP, Monge-Sanz BM, Morcrette J-J, Park B-K, Peubey C, de Rosnay P, Tavolato C, Thépaut J-N, Vitart F (2011) The ERA-Interim reanalysis: configuration and performance of the data assimilation system. Quarterly Journal of the Royal Meteorological Society 137, 553-597.

Dury M, Hambuckers A, Warnant P, Henrot A, Favre E, Ouberdous M, François L (2010) Responses of European forest ecosystems to 21 st century climate: assessing changes in interannual variability and fire intensity. iForest Biogeosciences and Forestry 4, 82-99.

Giglio L, Descloitres J, Justice CO, Kaufman YJ (2003) An enhanced contextual fire detection algorithm for MODIS. Remote Sensing of Environment 87, 273-282.

Justice CO, Korontzi SA (2001) A review of the status of satellite fire monitoring and the requirements for global environmental change research. In 'Global and regional vegetation fire monitoring from space: planning a coordinated international effort'. (Eds FJ Ahern, JG Goldammer, CO Justice) pp. 1-18. (SPB Academic Publishing: New York, NY, USA).

Justice CO, Giglio L, Korontzi S, Owens J, Morisette JT, Roy D, Descloitres J, Alleaume S, Petitcolin F, Kaufman Y (2002) The MODIS fire products. Remote Sensing of Environment 83, 244-262.

Kaufman YL, Justice CO, Flynn L, Kendall JD, Prins E, Giglio L, Ward DE, Menzel WP, Setzer AW (1998) Potential global fire monitoring from EOS-MODIS. Journal of Geophysical Research 103, 215-238.

Oom D, Pereira JMC (2013) Exploratory spatial data analysis of global MODIS active fire data. International Journal of Applied Earth Observation and Geoinformation 21, 326-340.

Pereira MG, Trigo RM, DaCamara CC, Pereira JMC, Leite SM (2005) Synoptic patterns associated with large summer forest fires in Portugal. Agricultural and Forest Meteorology 129, 11-25.

Pereira MG, Malamud BD, Trigo RM, Alves PI (2011) The history and characteristics of the 19802005 Portuguese rural fire database. Natural Hazards and Earth System Science 11, 3343 - 3358.

Pereira MG, Calado TJ, DaCamara CC, Calheiros T (2013) Effects of regional climate change on rural fires in Portugal. Climate Research 57,187-200.

Rasilla DF, García-Cordon JC, Carracedo V, Concepción D (2010) Circulation patterns, wildfire risk and wildfire occurrence at continental Spain. Physics and Chemistry of the Earth 35, 553-560.

Trigo RM, Pereira JM, Pereira MG, Mota B, Calado MT, DaCamara CC, Santo FE (2006) The exceptional fire season of summer 2003 in Portugal. International Journal of Climatology 26, 17411757. 
Trigo RM, Sousa PM, Pereira MG, Rasilla D, Gouveia CM (2013) Modelling wildfire activity in Iberia with different atmospheric circulation weather types. International Journal of Climatology, doi: 10.1002/joc.3749.

Schmuck G, San-Miguel-Ayanz J, Camia A, Durrant T, Boca R, Libertá G, Schulte E (2013): Forest fires in Europe, Middle East and North Africa 2012. Publications Office of the European Union, JRC Technical Reports. 